\title{
Adaptive Ability and Stability of the Genotypes of Collection Samples of Green Beans in Siberia
}

\author{
O.E. Yakubenko, O.V. Parkina, Z.V. Andreeva, G.Yu. Chepurnov
}

\begin{abstract}
The interaction of the genotype with individual groups of factors has long been the research subject of plant breeders and geneticists. The phenomenon of the "genotype-environment" interaction accompanies the entire history of plant breeding. Due to the necessity of expanding the area of green beans cultivation and the climatic variability, assessing the gene pool of this crop by its adaptive ability and stability for isolating highly plastic and stable genotypes with high productivity is quite relevant. This task is also important for searching for genotypes resistant to biotic and abiotic stress. The article provides an assessment of the adaptive ability and stability of the following green beans varieties: overall adaptive ability, variance of the specific adaptive ability, relative stability, and breeding value of the genotype. The studies were performed at the experimental field of the Garden of Michurinists Educational and Production Farm of the Novosibirsk State Agricultural University. In 2015 - 2018, the authors studied the adaptive ability and stability of 16 varieties of bushy green beans by the main components of the crop productivity. The adaptive ability, the relative stability, and the selective value of the genotypes were determined by the method of A. V. Krichevsky, according to which the adaptive ability is the ability of a genotype to maintain its inherent phenotypic manifestation of the trait in particular environmental conditions. The overall adaptive ability (OAA) of the genotype characterizes the average value of a trait in various environmental conditions, and the specific adaptive ability (SAA) - a deviation from the OAA in a particular environment. The analyzed parameters were calculated by the yield of green beans based on the results of four years of hybrids cultivation. The comparative analysis of common green bean varieties showed a wide polymorphism in terms of the $O A A$, the $S A A$, and the breeding values of the genotypes (BVG). This allows identifying promising genotypes to be included in the selection process by certain characteristics.
\end{abstract}

Keywords: common beans, variety, coefficient of variation, overall adaptive ability, specific adaptive ability, screening, relative stability, plasticity, Western Siberia.

\section{INTRODUCTION}

\section{$\mathrm{P}$} roduction of any crop is based on choosing the variety [1]. Based on the chosen variety, the main requirements for the technology of cultivation are determined. Plant variety,

Revised Manuscript Received on December 30, 2019.

* Correspondence Author

O.E. Yakubenko*, Novosibirsk State Agrarian University, Novosibirsk, Russia.

O.V. Parkina, Novosibirsk State Agrarian University, Novosibirsk, Russia. Z.V. Andreeva, Novosibirsk State Agrarian University, Novosibirsk, Russia.

G.Yu. Chepurnov, Novosibirsk State Agrarian University, Novosibirsk, Russia.

(C) The Authors. Published by Blue Eyes Intelligence Engineering and Sciences Publication (BEIESP). This is an open access article under the CC BY-NC-ND license (http://creativecommons.org/licenses/by-nc-nd/4.0/) being the basis for the technology of cultivating any crop, is the result of a complex interaction between the genotype and the environment, since it can implement its potential in terms of the yield and its technological quality only in certain soil and climatic conditions [2, 3]. In fact, creating a variety involves not only obtaining and screening new genotypes, but also searching for an ecological niche where this genotype will ensure high performance, environmental stability, and high quality of the product [4].

The interaction between the genotype and individual groups of factors is the subject of studies of many scientists, including plant breeders and geneticists $[5,6]$. Today, the nature of the interaction between plant genotypes and the abiotic factors is well studied, unlike the interaction with the biotic factors. In the plant breeding, the interaction between the genotype and the environment has two main aspects: assessment of the adaptive ability and genotype stability in different environments, and assessment of the growing conditions by their suitability to be used as the background for the screening $[7,8]$.

A. V. Kilchevsky [9] understands the adaptive ability as the ability of the genotype to maintain the phenotypic manifestation of a trait in particular environmental conditions. With that, the overall adaptive ability (OAA) characterizes the average value of a trait in various environmental conditions, the specific adaptive ability (SAA) - a deviation from the OAA in a particular environment.

Allen F.L., Comstorck R.E., Rasmusson D.C. et al. described the basic parameters of the environment as the background for screening - typicality, the genotypes' ability to identify variability (differentiating ability), productivity, and repeatability of these parameters throughout the year and upon changes in the set of genotypes [10-12].

Due to the necessity of expanding the area of green beans cultivation and the climatic variability, assessing the gene pool of this crop by its adaptive ability and stability for isolating highly plastic and stable genotypes with high productivity is quite relevant. This task is also important for searching for genotypes resistant to the biotic and abiotic stress. The authors studied the adaptive ability and stability of 16 varieties of bushy type green beans by productivity. The adaptive ability, the relative stability, and the selective value of the genotypes were determined by the method of A. V. Krichevsky [9], according to which the adaptive ability was the ability of a genotype to maintain its inherent phenotypic manifestation of the trait in particular environmental conditions. The analyzed parameters were calculated by the yield of green beans based on the results of four years of hybrids cultivation. The study was aimed at assessing the adaptive ability and stability of the genotypes of green beans in the conditions of Western Siberia. 


\section{PROPOSED METHODOLOGY}

\section{A. General description}

The studies were performed in 2015 - 2018 at the experimental field of the Garden of Michurinists Educational and Production Farm of the Novosibirsk State Agrarian University in Novosibirsk.

The experimental plot was located in the drained forest-steppe on the slopes of the Ob plateau. The fields were divided into rectangles bordered by wind belts. The climate was sharply continental.

The soil in the experimental plot was gray forest heavy loamy soil on carbonate-free heavy loam.

The objects of the study were varieties of bushy common green beans (Phaselous vulgaris L.) of various ecological and geographical origin. The standards were Siberian-bred green beans varieties Nika (an early maturing variety) and Solnyshko (a midseason-ripening variety). These varieties feature the high quality of the beans, they are adapted to the Siberian conditions, suitable for mechanized cultivation, and boast high and stable yields of beans and seeds.

\section{B. Algorithm}

The adaptive ability and stability of the genotypes were studied in accordance with the procedure of A. V. Kilchevsky [9]. A. V. Kilchevsky et al. suggested the method of analyzing the interaction between the genotype and the environment (GEI), which allowed simultaneously analyzing the overall and specific adaptive ability of genotypes and assessing the environment as a background for screening.

The suggested method of assessing the OAA and the SAA is based on testing a population of $n$ genotypes in $m$ environments. The number of repetitions is $c$. Then

$x_{i k r}=u+v_{i}+d_{k}+(v d)_{i k}+e_{i k r}$,

where $x$ is the phenotypic value of the ith genotype grown in environment $k$ in $r$ repetitions; $u$ is the overall average of the entire set of phenotypes; $v_{i}$ is the effect of the $i$ th genotype; $d_{k}$ is the effect of $k$ environment; $(v d)_{i k}$ is the effect of interaction of the $i$ th genotype of the $k$ environment; $e_{i k r}$ is the effect due to accidental causes and assigned to the ikrphenotype.

The effect of the OAA of the ith genotype of $C C A_{i}$ is equal to $v_{i}$, the deviation from the sum $u+v_{i}$ will be the effect of the SAA of the $i$ th genotype in the $k$ environment - SAS $S_{i k}$.

It is suggested that the measure of the stability of the ith genotype should be the SAA variance:

Let us introduce the concept of the genotype relative stability:

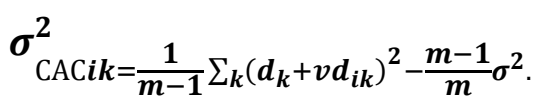

This indicator allows comparing the results of experiments with various sets of crops, genotypes, environments, and the traits studied.

$$
S_{g i}=\frac{\sigma_{S A A i k}}{u+O A A_{i}} 100 \%
$$

For the simultaneous screening by productivity and stability, it is suggested to use the breeding value of the genotype, which is calculated by the following formula:

$B V G_{i}=u+O A A_{i}-p \sigma_{S A A i}$

$$
\begin{gathered}
P=\frac{100}{2 \overline{s_{g}}} \\
\overline{S_{g}}=\frac{S_{g 1}+\ldots+S_{g n}}{n}
\end{gathered}
$$

The formula suggested for calculating the $B V G$ can only be used if screening is performed in the ascending order of the characteristic value. If genotypes are screened with the lowest value of the trait, the formula has the following form:

$B V G_{i}=u+O A A_{i}+p \sigma_{S A A i}$

All further calculations were performed following the above method of A. V. Kilchevsky.

In the studied years, the hydrothermal conditions were different. In 2015, favorable hydrothermal conditions for the growth and development of plants were observed. The average monthly temperature in May was $12.9^{\circ} \mathrm{C}$, i.e., $2.5^{\circ} \mathrm{C}$ above the norm. The rainfall was $73.3 \mathrm{~mm}$, which was $187.9 \%$ of the norm. In June, the average monthly temperature amounted to $19.2^{\circ} \mathrm{C}$, which was $2.2^{\circ} \mathrm{C}$ above the average monthly normal temperature, the rainfall amounted to $32.1 \mathrm{~mm}$, i.e., $71.3 \%$ of the norm. In the second and third decades of June, deficiency of moisture was observed. In July, the monthly average temperature was 19.6 ${ }^{\circ} \mathrm{C}$, which was $0.2^{\circ} \mathrm{C}$ above the norm, the rainfall in this month was $112.2 \mathrm{~mm}$, which was $181 \%$ above the norm. With that, the main part of the rainfall occurred in the first and the third decades of July. In August, the average monthly temperature was $17.1^{\circ} \mathrm{C}$ and exceeded the norm by $1.5^{\circ} \mathrm{C}$. The rainfall was $58.5 \mathrm{~mm}$ (84.8\% of the norm).

In 2016, the hydrothermal conditions for the growth and development of bean plants were favorable. At the end of the second decade of May, a collection nursery was laid. The air temperature was $+10^{\circ} \mathrm{C}$. The sprouts were even because of sufficient rainfall after sowing. The average temperature in May was only $10.3^{\circ} \mathrm{C}$, i.e., $0.6^{\circ} \mathrm{C}$ below the norm; the rainfall was $32 \mathrm{~mm}$, which was $86 \%$ of the norm. In the period between sowing and sprouts, slight heat deficiency was observed. The soil temperature did not reach the optimum of $10-12^{\circ} \mathrm{C}$. In June, the average monthly air temperature was $19.7^{\circ} \mathrm{C}$, which was $2.8^{\circ} \mathrm{C}$ above the norm; the rainfall was $38 \mathrm{~mm}$, i.e., $69 \%$ of the norm. In July, the average temperature was $20.2^{\circ} \mathrm{C}$, i.e., $0.8^{\circ} \mathrm{C}$ above the norm. The optimum ratio of air temperature and sufficient moisture content favored the intensive development of the vegetative mass of the plants and even fruiting.

The hydrothermal conditions in 2017 were optimal for the growth and development of green beans plants. The average temperature in May was $13.3^{\circ} \mathrm{C}$, i.e., $2.4^{\circ} \mathrm{C}$ above the norm. The rainfall was $27 \mathrm{~mm}$, i.e., $73 \%$ of the norm. In the third decade of May, moisture deficiency was observed, which increased the duration of the period between sowing and sprouts. In June, the average monthly temperature amounted to $19.2{ }^{\circ} \mathrm{C}$, which was $2.2{ }^{\circ} \mathrm{C}$ above the average monthly normal temperature, the rainfall amounted to $32.1 \mathrm{~mm}$, i.e., $71.3 \%$ of the norm. In July, the monthly average temperature was $18.5^{\circ} \mathrm{C}$, which was $0.9^{\circ} \mathrm{C}$ below the norm, the rainfall in this month was $100 \mathrm{~mm}$, which was $163 \%$ of the norm. With that, the main part of the rainfall occurred in the first and the third decades of July. 
In August, the average monthly temperature was $16.9^{\circ} \mathrm{C}$ and exceeded the norm by $0.7^{\circ} \mathrm{C}$. The rainfall was $65 \mathrm{~mm}$ (97\% of the norm).

The meteorological conditions in 2018 were unfavorable for the growth and development of bean plants. In May, rainy and cool weather prevailed — the average monthly temperature was $6.9^{\circ} \mathrm{C}$, i.e., $4^{\circ} \mathrm{C}$ below the norm, the rainfall was $81.0 \mathrm{~mm}$, i.e., $219 \%$ of the norm. In June, the average monthly air temperature was $19.1{ }^{\circ} \mathrm{C}$, which was $2.2^{\circ} \mathrm{C}$ above the norm; the rainfall was $71 \mathrm{~mm}$, i.e., $129 \%$ of the norm. In June, the average monthly air temperature was 16.6 ${ }^{\circ} \mathrm{C}$, which was $0.8{ }^{\circ} \mathrm{C}$ above the norm; the rainfall was 64.3 $\mathrm{mm}$, i.e., $105 \%$ of the norm.

\section{RESULT ANALYSIS}

In the breeding work, the method of genetic analysis proposed by A. V. Kilchevskiy et al. has become widespread, which is based on testing the genotypes in various environments and allowing one to identify the overall and specific adaptive ability of genotypes, their stability, their breeding value, and to perform screening by the adaptive capacity, depending on the determined screening task.

As a result of the studies, the adaptive ability and stability of 16 common green bean varieties were determined, depending on the cultivation conditions. The adaptive ability, the relative stability and the breeding value of the genotypes were determined following the specified method, where the adaptive capacity was understood as the ability of a genotype to maintain its inherent phenotypic manifestation of the trait in a particular environment. The analyzed parameters were calculated by the yield of green beans based on the results of four years of hybrids cultivation $(2015$ - 2018). The obtained data are shown in Table 1.

Table 1: Parameters of the adaptive ability and stability of green beans varieties yield

\begin{tabular}{|c|c|c|c|c|c|}
\hline No. & Cultivar & $\mathrm{Xi}, \mathrm{kg} / \mathrm{m}^{2}$ & OAAi (vi) & SAAi & Sgi \\
\hline \multicolumn{6}{|c|}{ Early maturing varieties } \\
\hline 1 & Nika st. & 8.2 & -1.6 & 39.55 & 78.4 \\
\hline 2 & Magura & 6.9 & -1.9 & 38.23 & 62.1 \\
\hline 3 & Sekunda & 7.4 & -1.8 & 37.36 & 53.2 \\
\hline 4 & Darina & 6.7 & -1.9 & 38.18 & 63.2 \\
\hline 5 & Maxi & 7.3 & -1.8 & 39.26 & 52.3 \\
\hline \multicolumn{6}{|c|}{ Mid-ripening varieties } \\
\hline 6 & Solnyshkost. & 11.4 & +0.01 & 86.75 & 76.9 \\
\hline 7 & Veronica & 7.9 & -1.9 & 85.81 & 43.2 \\
\hline 8 & Rocquentcant & 10.1 & +0.02 & 86.48 & 77.3 \\
\hline 9 & Peak & 7.4 & -2.0 & 78.54 & 54.5 \\
\hline 10 & Viola & 7.1 & -0.19 & 85.66 & 61.9 \\
\hline 11 & Zhuravushka & 7.2 & -1.3 & 87.24 & 40.1 \\
\hline 12 & Marusya & 7.2 & -1.5 & 74.62 & 47.9 \\
\hline 13 & Sibiryachka & 6.6 & +0.01 & 86.12 & 67.5 \\
\hline 14 & Yantarnaya & 5.4 & -1.6 & 57.32 & 55.3 \\
\hline 15 & Malakhit & 7.5 & -1.5 & 87.54 & 54.1 \\
\hline 16 & Ukrainka & 7.5 & -1.3 & 79.35 & 48.8 \\
\hline
\end{tabular}

The comparative analysis of the varieties of green beans revealed wide polymorphism by the OAA and the SAA. This allows identifying promising genotypes to be included in the selection process for creating highly productive crop varieties.

The highest OAA was found in varieties Rocquentcant, Solnyshko, and Sibiryachka, while the SAA varied from 38.18 (Darina) to 87.54 (Malakhit). The relative stability changed from 40.1 (Zhuravushka) up to 78.4 (Nika).

Thus, the varieties that were the experimental material varied by their adaptability: varieties Solnyshko and Rocquentcant were highly adaptive; varieties Nika, Sibiryachka and Darina were medium adaptive, and varieties Ukrainka and Malakhit were of the intensive type. Other varieties could be attributed to the group of medium adaptability.

\section{CONCLUSION}

1. By the hydrothermal conditions, the conditions of Western Siberia correspond to the biological needs of common bean.

2. It has been found that the varieties' productivity depends on the hydrothermal conditions in a particular year.

3. The breeding material has been studied by the degree of adaptability to the cultivation conditions.
4. Highly adaptive varieties (Solnyshko, Rocquentcant, Veronica), and medium adaptive varieties (Nika, Sibiryachka, Darina) have been identified.

\section{REFERENCES}

1. M. A. Vishnyakova,“Genofondzernobobovykh kultur iadaptivnayaselektsiyakakfaktorybiologizatsiiiekologizatsiirastenievods tva (obzor)" [The gene pool of legumes and the adaptive breeding as factors of biologization and ecologization of plant cultivation (review)], Agricultural biology, 3, 2008, pp. 3- 23.

2. O.E. Yakubenko,

O.V. Parkina,"Perspektivnyegenotipyfasoliovoshchnoi" [Promising genotypes of green beans], Actual Problems of The Agroindustrial Complex: Proceedings of the scientific-practical conference for teachers, graduate students, undergraduates and students of the Novosibirsk State Agrarian University. RC "ZolotoyKolos", 2018, pp. $56-59$.

3. G.S. Posypanov, E. Dolgodvorov, B.H. Zherukov, "Rastenievodstvo" [Crop breeding]. Moscow: KolosS, 2007, p. 612.

4. L.L. Eremenko, "Morfologicheskieosobennostiovoshchnykhrastenii v svyazi s semennoiproduktivnostyu" [Morphological features of vegetable plants with regard to the seed yield]. Novosibirsk: Nauka, 1975, p. 472. 
5. O.E. Yakubenko,

Parkina,"Vyrazhennostiizmenchivostkhozyaistvennotsennykhpriznako vfasoliobyknovennoi v zavisimostiotgenotipaiusloviivyrashchivaniya" [Severity and variability of economically valuable traits of common bean depending on the genotype and the growing conditions]. Youth and Science of The Xxi Century: Materials of the International scientific conference.Ulyanovsk state agrarian University n.a. P. A. Stolypin, 2017, pp. 136-140.

6. Y.A. Filimonova, Vishnyakova,“Adaptivnayasposobnostistabilnostkollektsionnykhobrazt sovsortovfasoliovoshchnogoispolzovaniya" [The adaptive ability and stability of collection samples of general purpose green beans varieties]. SPb.: All-Russian Research Institute of Plant Breeding (VIR), Works in applied botanic, botany and breeding,166, 2009, pp. 286 - 290.

7. M.A. Vishnyakova, "Rolgenofondazernobobovykh kultur v resheniiaktualnykhzadachselektsii,

rastenievodstvaipovysheniyakachestvazhizni” [The role of the legumes gene pool in resolving the actual problems of plant breeding, crop production and improving the quality of life].SPb.: VIR, Works in applied botany, genetics, and plant breeding, 2, 2007, pp. $101-118$.

8. O.V. Parkina, N.P. Goncharov, O.E. Yakubenko, "Vyborsortovfasoliovoshchnoidlyarazrabotkikonveierasyrya v usloviyakhlesostepiPriobya" [Choosing varieties of green beans for developing a raw materials chain in the conditions of the forest-steppe of the Ob region]. Theory and Practice of Modern Agrarian Science: a collection of national (All-Russian) scientific conference. RC "ZolotoyKolos", 2018, pp. 56 - 60.

9. A.V. Kilchevsky, "Genetiko-ekologicheskieosnovyselektsiirastenii" [Genetic and ecological bases of plant breeding]. Belarus, News of the Vavilov Society of Geneticists and Breeders (VOGiS), 4(9), 2005, pp. $518-526$.

10. M.E.Alladassi, S. Nkaludo, C. Mukankusi, E. Mwale, P. Gibson, R. Edema, C. Urrea, J. Kelly, P. Rubaihayo,"Inheritance of resistance to common bacterial blight in four selected common beans (Phaseolus vulgaris L.) genotypes", Journal of Plant Breeding and Crop Science, 9(6), 2017, pp. 71-78.

11. F.L. Allen, R.E. Comstorck, D.C. Rasmusson,“Optimal environments for yield testing”, Crop. Sci., 5(18), 1978, pp. 747-751.

12. D.Belarmino, Inheritance of resistance to common bacterial blight (Xanthomonas campestris pv. phaseoli) disease and yield of common bean: Master thesis. Makerere Universaty, 2015.

\section{AUTHORS PROFILE}

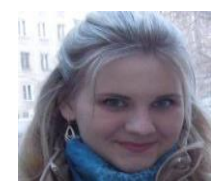

O.E. Yakubenko, Graduate student, Faculty of Agronomy, Novosibirsk State Agrarian University. Author of over 36 publications.

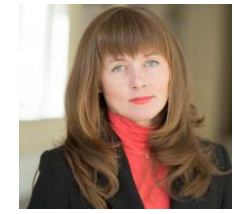

O.V. Parkina, Candidate of Agricultural Sciences, Associate Professor

The author of more than 70 publications. Constantly improves qualifications, taking an internship at the FPK in Novosibirsk, Moscow, Krasnoyarsk.

Since 1993, he has been dealing with issues of selection and genetics of legumes. As a result of experimental breeding work, new varieties of vegetable beans were created, entered into the State Register of selection achievements allowed for use in the Russian Federation: Darina, Solnyshko, Yantarnaya, Viola (2010); Nick, Anniversary (2013).

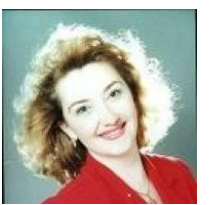

Z.V. Andreeva, Doctor of Biological Sciences, Associate Professor, Head of the Department of Independent Evaluation of the Quality of Education.

G.Yu. Chepurnov,student of Novosibirsk State Agrarian University.Participation in conferences:

Intra-university conference "Competition for the best scientific work among students", nomination "Agronomy".

II stage of the All-Russian competition for the best scientific work among students, graduate students and young scientists of agricultural universities of the Ministry of Agriculture of the Russian Federation, nomination "Agronomy".

II stage of the All-Russian competition for the best scientific work among students, graduate students and young scientists of universities of the Ministry of Agriculture of the Russian Federation ", nomination" Agronomy". 